\title{
PENGARUH KOMPETENSI DAN DISIPLIN KERJA TERHADAP MOTIVASI DAN DAMPAKNYA PADA KINERJA PEMERIKSA FORENSIK PUSLABFOR BARESKRIM POLRI
}

\author{
Yuswardi \\ Program Pasca Sarjana Manajemen \\ Sekolah Tinggi Ilmu Ekonomi Indonesia \\ yuswardi79@gmail.com
}

\begin{abstract}
ABSTRAK
Tugas pokok Puslabfor Bareskrim Polri adalah melakukan pemeriksaan barang bukti dan melaksanakan Olah Tempat Kejadian Perkara, tidak dapat dilepaskan dari kinerja Pemeriksa Forensik Puslabfor Bareskrim Polri. Kinerja menjadi fenomena yang menarik untuk diteliti karena banyak faktor yang mempengaruhinya. Penelitian ini bertujuan untuk mengetahui pengaruh kompetensi dan disiplin kerja terhadap motivasi dan dampaknya pada kinerja pemeriksa Forensik Puslabfor Bareskrim Polri. Metode sensus dipergunakan dalam penentuan sampel. Pengumpulan data primer melalui kuesioner disebar kepada 78 orang responden. Penelitian dianalisis menggunakan regregi linier berganda dengan uji path dan uji Sobel dengan menunjukkan hasil : 1) Kompetensi berpengaruh secara langsung terhadap kinerja, 2) Disiplin kerja berpengaruh secara langsung terhadap kinerja, 3) Kompetensi berpengaruh secara langsung terhadap motivasi 4) Disiplin kerja berpengaruh langsung terhadap motivasi, 5) Motivasi berpengaruh langsung terhadap kinerja, 6) Kompetensi berpengaruh secara tidak langsung terhadap kinerja melalui motivasi, 7) Disiplin kerja tidak berpengaruh secara tidak langsung terhadap kinerja melalui motivasi, 8) Kompetensi dan disiplin kerja secara simultan berpengaruh terhadap motivasi, 9) Kompetensi, disiplin kerja dan motivasi secara simultan berpengaruh terhadap kinerja pemeriksa Forensik Puslabfor Bareskrim Pori.
\end{abstract}

Kata kunci : kompetensi, disiplin kerja, motivasi, kinerja pemeriksa Forensik

\begin{abstract}
The main tasks of the Indonesian National Police, Criminal Investigation Division, Central Forensic Laboratory are to conduct evidence examination and carry out crime scene processing, which are inseparable from the performance of the Central Forensic Laboratory's forensic examiners. Performance is an interesting phenomenon to study due to the fact that there is a multitude of factors influencing it. This study aims to determine the effects of work competence and discipline on motivation and its impact on the performance of forensic examiners. The census method is used in sample determination. Primary data collection through questionnaires were distributed to 78 respondents. The research was analyzed using multiple linear regression with path analysis and Sobel test by showing the results: 1) Competence directly influences performance, 2) Work discipline directly influences performance, 3) Competence directly influences motivation 4) Work discipline has a direct effect on motivation, 5) Motivation directly affects performance, 6) Competence indirectly affects performance through motivation, 7) Work discipline does not indirectly affect the performance through motivation, 8) Competence and work discipline simultaneously affect motivation, 9) Competence, work discipline and motivation simultaneously affect the performance of forensic examiners.
\end{abstract}

Key words: competence, work discipline, motivation, performance of forensic examiner

\section{PENDAHULUAN}

Kinerja menjadi isu dunia saat ini, hal tersebut terjadi sebagai konsekuensi tuntutan masyarakat terhadap kebutuhan akan pelayanan prima atau pelayanan yang bermutu tinggi. Kinerja menurut Robbins 1996 dalam Sinambela (2017 : 480) diartikan 


\section{Pengaruh Kompetensi Dan Disiplin Kerja Terhadap Motivasi Dan Dampaknya Pada Kinerja Pemeriksa \\ Forensik Puslabfor Bareskrim Polri \\ (Yuswardi)}

sebagai hasil evaluasi terhadap pekerjaan yang dilakukan individu dibandingkan dengan kriteria yang telah ditetapkan bersama. Seorang karyawan yang memiliki kinerja yang tinggi dapat menunjang tercapainya tujuan dan sasaran yang telah ditetapkan oleh organisasi. Kinerja juga merupakan tolak ukur keberhasilan suatu organisasi, semakin baik kinerja suatu organisasi maka pencapaian target-target yang telah ditetapkan akan mudah terwujud. Kinerja yang baik tentu saja merupakan harapan bagi semua organisasi atau perusahaan yang mempekerjakan karyawan, sebab kinerja karyawan ini pada akhirnya diharapkan dapat meningkatkan kinerja organisasi secara keseluruhan.

Untuk mendapatkan kinerja yang optimal tidaklah mudah, berbagai faktor dapat mempengaruhi kinerja diantaranya adalah kompetensi, disiplin kerja dan motivasi. Sebagai sebuah organisasi, Kepolisian Republik Indonesia (POLRI) dituntut untuk dapat memberikan pelayanan terbaik kepada masyarakat. Sesuai dengan Grand Strategi Polri 2005-2025, rencana pembangunan jangka panjang Polri dibagi menjadi 3 (tiga) tahap yaitu : Tahap I Trust Building (2005-2010) yaitu membangun kepercayaan masyarakat kepada Polri, tahap II Partnership (2011-2015) yaitu membina kemitraan dengan masyarakat dalam rangka mendukung tugas Polri, dan Tahap III Strive of excelence (20162025) yaitu memberikan pelayanan terbaik kepada masyarakat.

Dalam rangka memberikan pelayanan terbaik kepada masyarakat, Pusat Laboratorium Forensik Bareskrim Polri (Puslabfor Bareskrim Polri) sebagai bagian dari institusi polri mendukung sepenuhnya kebijakan Kapolri saat ini dalam rangka meningkatkan kepercayaan masyarakat terhadap institusi Polri yaitu melalui program Promoter (Profesional, Modern dan Terpercaya), sesuai dengan lingkup tugas pokok Puslabfor Bareskrim Polri yaitu melakukan pemeriksaan tempat kejadian perkara (TKP) dan barang bukti secara ilmiah dalam rangka mendukung penyelidikan dan penyidikan (Scientific Crime Investigation).

Tolak ukur kinerja pemeriksa Forensik Puslabfor Bareskrim Polri dapat terlihat dari penyelesaian kasus pemeriksaan barang bukti yang masuk sesuai dengan Analisa Beban Kerja (ABK) Puslabfor Bareskrim polri. Tercatat bahwa penyelesaian kasus pemeriksaan barang bukti dari tahun 2012 sampai dengan 2016 berdasarkan analisa beban kerja (ABK Puslabfor Bareskrim Polri) terlihat mengalami penurunan, terutama untuk penyelesaian kasus kategori sedang dan berat, dimana maksimal waktu penyelesaian perkara kasus ringan adalah 5 hari, kasus sedang 14 hari dan kasus berat 30 hari.

Puslabfor Bareskrim Polri mempunyai ciri khas bila dibandingkan dengan instansi-instansi lainnya dibawah Polri karena lingkup pekerjaannya yang spesifik dan ilmiah sehingga dibutuhkan kompetensi khusus. Semakin kompeten personil dalam melakukan pekerjaannya maka kinerja organisasi akan meningkat. Dari data tabel 1.1, diduga ada kaitan antara kompetensi pemeriksa Forensik Puslabfor Bareskrim Polri dengan kinerja terkait penyelesaian kasus terutama kasus-kasus kategori sedang dan berat.

Faktor lainnya yang dapat menjadi penyebab penurunan kinerja pemeriksa Forensik Puslabfor Bareskrim Polri adalah Disiplin kerja. Dari data presentase kehadiran pemeriksa Forensik Puslabfor Bareskrim Polri dari bulan Januari s.d Desember 2017 terlihat pemeriksa Forensik yang hadir penuh pada jam kerja dari pukul 07.00 s.d 15.00 WIB hanya berkisar 40 $\%$ - $55 \%$. Rendahnya tingkat kehadiran dikarenakan pemeriksa Forensik yang sering masuk kantor terlambat dan pulang lebih cepat dari waktu kerja serta sering ijin meninggalkan kantor. Data tersebut memperlihatkan bahwa tingkat disiplin kerja Pemeriksa Forensik Puslabfor Bareskrim Polri masih rendah dan diduga mempengaruhi kinerja organisasi.

Motivasi juga diduga sebagai faktor penyebab penurunan kinerja. Dari hasil wawancara peneliti dengan rekan-rekan kerja, beberapa faktor tersebut antara lain minimnya perhatian pimpinan terhadap pengembangan karir personil seperti tidak adanya quota untuk anggota Polri yang akan mengikuti pendidikan lanjutan Kepolisian (Sespimma, Sespimmen dan Sespimti), tidak adanya "Reward dan Punisment", kompensasi berupa tunjangan kinerja yang tidak berbanding lurus dengan beban kerja dan ruangan kerja yang tidak nyaman dimana saat ini Puslabfor Bareskrim Polri yang seluruhnya berjumlah 156 personil menduduki gedung Dinas Koperasi dan UMKM Pemda DKI yang berdaya tampung maksimal 90 personil belum termasuk peralatan-peralatan Laboratorium.

Berdasarkan pada uraian tersebut diatas, maka penulis tertarik untuk meneliti mengenai pengaruh kompetensi dan disiplin kerja terhadap motivasi dan dampaknya pada kinerja pemeriksa forensik Puslabfor Bareskrim Polri”.

\section{TINJAUAN PUSTAKA}

Kompetensi adalah karakteristik dasar seseorang yang berkaitan dengan efektivitas kinerja didasarkan atas pengetahuan, keterampilan dan sikap yang membuat orang tersebut mampu memenuhi apa yang diisyaratkan oleh pekerjaan dalam suatu organisasi.

Menurut Spencer dalam Moeheriono (2014:14) kompetensi dasar seorang individu terdiri atas 5 hal, yaitu 
1. Watak (traits), yaitu yang membuat seseorang mempunyai sikap perilaku atau bagaimanakah orang tersebut merespon sesuatu dengan cara tertentu.

2. Motif (motive), yaitu sesuatu yang diinginkan seseorang atau secara konsisten dipikirkan dan diinginkan yang mengakibatkan suatu tindakan.

3. Konsep diri (self-concept), adalah sikap dan nilainilai yang dimiliki seseorang. Sikap dan nilai tersebut dapat diukur melalui tes untuk mengetahui nilai yang dimiliki.

4. Pengetahuan (knowledge), yaitu informasi yang dimiliki seseorang pada bidang tertentu atau pada arena terentu.

5. Keterampilan atau keahlian (skill), yaitu kemampuan untuk melaksanakan tugas tertentu baik secara fisik maupun mental.

Disiplin kerja merupakan kebiasaan diri untuk dapat mengerjakan suatu aturan dan norma sosial dengan penuh sukarela yang bertujuan untuk mencapai segala sesuatu yang diharapkan. Sebagai pegawai, maka harus memiliki rasa disiplin yang tinggi, agar apapun yang telah menjadi tujuan dan harapan organisasi dapat tercapai sesuai dengan yang diharapkan.

Menurut Singodimedjo 2000 dalam Sutrisno (2016 : 89), faktor-faktor yang mempengaruhi disiplin pegawai adalah :

1. Besar kecilnya pemberian kompensasi

2. Ada tidaknya keteladanan pimpinan dalam organisasi

3. Ada tidaknya aturan pasti yang dapat dijadikan pegangan

4. Keberanian pimpinan dalam mengambil tindakan

5. Ada tidaknya pengawasan pimpinan

6. Ada tidaknya perhatian kepada para pegawai

Motivasi merupakan dorongan baik dari dalam maupun luar individu yang penting dalam suatu organisasi yang berfungsi untuk pencapaian tujuan atau sasaran yang ingin dicapai. Dikutip dalam buku Donni Juni Priansa (2014 : 205-212) beberapa teori motivasi tersebut antara lain :

1. Teori Hirarki Kebutuhan Maslow

2. Teori Kebutuhan Berprestasi McClelland

3. Teori Dua Faktor Herzberg

Kinerja adalah tingkat keberhasilan yang dicapai oleh seorang pegawai di dalam pekerjaannya yang diukur selama periode waktu tertentu, yang didalamnya terlihat bagaimana kualitas dan kuantitas seorang pegawai dalam mengerjakan suatu pekerjaan. Dimensi yang menunjang Kinerja, menurut John Miner 1988 dalam Edison (2017 : 192) yaitu :

1. Kualitas, yaitu tingkat kesalahan, kerusakan, kecermatan.

2. Kuantitas, yaitu jumlah pekerjaan yang dihasilkan.

3. Penggunaan waktu dalam kerja, yaitu tingkat ketidakhadiran, keterlambatan, waktu kerja efektif/jam kerja hilang.

4. Kerja sama dengan orang lain dalam bekerja. ichẹ

\section{METODOLOGI PENELITIAN}

Metode yang digunakan menggunakan kuantitatif dengan populasi seluruh pemeriksa Forensik di Puslabfor Bareskrim Polri yang terkait dengan pemeriksaan berkas perkara di masing-masing Bidang yaitu Narkobafor, Kimbiofor, Fiskomfor, Balmetfor dan Dokupalfor, dengan jabatan Kepala Bidang (Kabid), Kepala Sub Bidang (Kasubbid), Kepala Urusan (Kaur), Perwira Urusan (Paur), Perwira Administrasi (Pamin) dan Jabatan Fungsional sebagai Pemeriksa seluruhnya berjumlah 78 personil pada tahun 2017. Teknik sampling yang digunakan pada penelitian ini adalah sampling jenuh. Penelitian ini terdapat tiga variabel, yaitu variabel dependen, variabel intervening/mediasi dan variabel independen. Dengan variabel dependen adalah kinerja yang dilambangkan dengan Z. Variabel intervening yang digunakan adalah motivasi yang dilambangkan dengan Y. Dan Pada penelitian ini variabel independen yang digunakan adalah Kompetensi dan Disiplin Kerja yang dilambangkan dengan $\mathrm{X}$.

Metode yang digunakan untuk menguji validitas pada penelitian ini adalah menggunakan program SPSS (Statistical Package for Social Science), dengan membandingkan nilai $r$ hitung pearson correlation terhadap $r$ tabel product moment dengan $\alpha=0,05$ dan jumlah sampel (n) sebanyak 78. Jika hasilnya signifikan maka indikator pada masing-masing pertanyaan adalah valid. Selanjutnya Uji reliabilitas dapat dilakukan dengan menggunakan bantuan program SPSS, memberikan fasilitas untuk mengukur reliabilitas dengan uji statistik Cronbach Alpha $(\alpha)$. Suatu konstruk atau variabel dikatakan reliabel jika memberikan nilai Cronbach Alpha > 0.70 (Nunnally dalam Ghozali, 2016 : 48).

Analisis regresi linier digunakan untuk mengetahui ada tidaknya pengaruh antara Kompetensi, Disiplin Kerja terhadap Motivasi dan dampaknya pada Kinerja.

Dalam regresi linier berganda terdapat 4 variabel, yaitu:

1. Variabel Bebas, yaitu Kompetensi (X1), Disiplin Kerja (X2) 
2. Variabel Intervening, yaitu Motivasi Kerja (Y) 3. Variabel Terikat, yaitu Kinerja (Z) Untuk menguji variabel tersebut maka digunakan analisis regresi linier berganda dengan rumus sebagai berikut : $\mathrm{Y}$

$Z=\beta 1 Z 3 X 1+\beta 2 Z X 2+\beta 5 Z Y$

$\beta 3 \mathrm{YX} 1+\beta 4 \mathrm{YX} 2$

Dimana:

$\mathrm{X} 1=$ Sebagai variabel independen exogenous Kompetensi X2 = Sebagai variabel independen exogenous Disiplin Kerja $\mathrm{Y}=$ Sebagai dependen endogenous perantara Motivasi

$\mathrm{Z}=$ Sebagai dependen endogenous Kinerja

$\beta=$ Koefesien regresi variabel

\section{HASIL DAN PEMBAHASAN}

Pengaruh langsung Kompetensi terhadap Kinerja (H1)

Koefisien regresi $(\beta)$ pengaruh Kompetensi terhadap Kinerja sebesar 0,440 yang memerlihatkan arah pengaruh positif. Nilai t hitung $(4,917)>t$ tabel $(1,993)$ untuk $\mathrm{df}=74$, dengan signifikansi $0,000<\operatorname{sig} \alpha(0,05)$. Dengan demikian, H1 diterima dan H0 ditolak, sehingga hipotesis pertama : Kompetensi berpengaruh langsung terhadap Kinerja pemeriksa Forensik Puslabfor Bareskrim Polri diterima.

\section{Pengaruh langsung Disiplin Kerja terhadap Kinerja (H2)}

Koefisien regresi $(\beta)$ pengaruh Disiplin Kerja terhadap Kinerja sebesar 0,191 yang memerlihatkan arah pengaruh positif. Nilai t hitung $(2,177)>$ t tabel $(1,993)$ untuk $\mathrm{df}=74$, dengan signifikansi $0,033<\operatorname{sig} \alpha(0,05)$. Dengan demikian, H2 diterima dan H0 ditolak, sehingga hipotesis kedua : Disiplin Kerja berpengaruh langsung terhadap Kinerja pemeriksa Forensik Puslabfor Bareskrim Polri diterima.

Pengaruh langsung Kompetensi terhadap Motivasi (H3)

Koefisien regresi ( $\beta$ ) pengaruh Kompetensi terhadap Motivasi sebesar 0,386 yang memerlihatkan arah pengaruh positif. Nilai t hitung $(3,026)>t$ tabel $(1,992)$ untuk $d f=75$, dengan signifikansi $0,003<\operatorname{sig} \alpha$ $(0,05)$. Dengan demikian, H3 diterima dan H0 ditolak, sehingga hipotesis ketiga : Kompetensi berpengaruh langsung terhadap Motivasi pemeriksa Forensik Puslabfor Bareskrim Polri diterima.

\section{Pengaruh langsung Disiplin Kerja terhadap Motivasi} (H4)

Koefisien regresi $(\beta)$ pengaruh Disiplin Kerja terhadap Motivasi sebesar 0,299 yang memerlihatkan arah pengaruh positif. Nilai t hitung $(2,343)>t$ tabel $(1,992)$ untuk $\mathrm{df}=75$, dengan signifikansi $0,022<\operatorname{sig} \alpha$ $(0,05)$. Dengan demikian, H4 diterima dan H0 ditolak, sehingga hipotesis keempat : Disiplin Kerja berpengaruh langsung terhadap Motivasi pemeriksa Forensik Puslabfor Bareskrim Polri diterima.

Pengaruh langsung Motivasi Terhadap Kinerja (H5)

Koefisien regresi $(\beta)$ pengaruh Motivasi terhadap Kinerja sebesar 0,355 yang memerlihatkan arah pengaruh positif. Nilai t hitung $(4,645)>t$ tabel $(1,993)$ untuk $\mathrm{df}=74$, dengan signifikansi $0,000<\operatorname{sig} \alpha(0,05)$. Dengan demikian, H5 diterima dan H0 ditolak, sehingga hipotesis kelima : Motivasi berpengaruh langsung terhadap Kinerja pemeriksa Forensik Puslabfor Bareskrim Polri diterima.

Pengaruh tidak langsung Kompetensi terhadap Kinerja dengan Motivasi sebagai variabel Intervening (H6)

Besarnya pengaruh langsung Kompetensi terhadap Kinerja sebesar 0,440, sedangkan pengaruh tidak langsungnya melalui Motivasi sebesar 0.137 dan pengaruh totalnya sebesar 0,577. Berdasarkan data tersebut diketahui bahwa pengaruh langsung Kompetensi terhadap Kinerja lebih besar daripada pengaruh tidak langsungnya. Dari hasil perhitungan Uji Sobel diperoleh nilai Z hitung $(2,502)>Z$ tabel $(1,96)$ dengan signifikasi 0,05 , sehingga posisi Motivasi sebagai variabel intervening/mediasi signifikan mempengaruhi hubungan Kompetensi terhadap Kinerja. Dengan demikian, H6 diterima dan H0 ditolak, sehingga Hipotesis keenam yang menyatakan bahwa Kompetensi berpengaruh tidak langsung terhadap Kinerja pemeriksa Forensik Puslabfor Bareskrim Polri yang dimediasi oleh Motivasi diterima.

\section{Pengaruh tidak langsung Disiplin Kerja terhadap Kinerja dengan Motivasi sebagai variabel Intervening (H7)}

Besarnya pengaruh langsung Disiplin Kerja terhadap Kinerja sebesar 0,191, sedangkan pengaruh tidak langsungnya melalui Motivasi sebesar 0.106 dan pengaruh totalnya sebesar 0,297. Berdasarkan data tersebut diketahui bahwa pengaruh langsung Disiplin Kerja terhadap Kinerja lebih besar daripada pengaruh tidak langsungnya. Dari hasil perhitungan Uji Sobel diperoleh nilai Z hitung $(1,789)<\mathrm{Z}$ tabel $(1,96)$ dengan signifikasi 0,05 , sehingga posisi Motivasi sebagai variabel intervening/mediasi tidak signifikan mempengaruhi hubungan Kompetensi terhadap Kinerja. Dengan demikian, H6 ditolak dan H0 diterima, sehingga Hipotesis ketujuh yang menyatakan bahwa Disiplin Kerja berpengaruh tidak langsung terhadap Kinerja 
pemeriksa Forensik Puslabfor Bareskrim Polri yang dimediasi oleh Motivasi ditolak.

\section{Pengaruh Kompetensi dan Disiplin Kerja terhadap Motivasi (H8)}

Hasil uji $\mathrm{F}$ yang digunakan untuk menguji hipotesis menunjukkan nilai $\mathrm{F}$ hitung $(25,463)>\mathrm{F}$ tabel $(3,112)$ untuk df1 $=2$ dan df1 $=74$, dengan signifikansi $0,000<\operatorname{sig} \alpha(0,05)$. Dengan demikian, H8 diterima dan H0 ditolak, sehingga hipotesis kedelapan : Kompetensi dan Disiplin Kerja secara simultan berpengaruh terhadap Motivasi Pemeriksa Forensik Puslabfor Bareskrim Polri diterima.

\section{Pengaruh Kompetensi, Disipilin Kerja dan Motivasi terhadap Kinerja (H9)}

Hasil uji $\mathrm{F}$ yang digunakan untuk menguji hipotesis menunjukkan nilai $\mathrm{F}$ hitung $(71,088)>\mathrm{F}$ tabel $(2,73)$ untuk df1 $=3$ dan df1 $=74$, dengan signifikansi $0,000<\operatorname{sig} \alpha(0,05)$. Dengan demikian, H9 diterima dan H0 ditolak, sehingga hipotesis kesembilan : Kompetensi, Disiplin Kerja dan Motivasi secara simultan berpengaruh terhadap Kinerja Pemeriksa Forensik Puslabfor Bareskrim Polri diterima.

\section{KESIMPULAN}

Berdasarkan hasil analisis data melalui pembuktian kesembilan hipotesis yang diajukan pada penelitian ini mengenai pengaruh Kompetensi dan Disiplin Kerja terhadap Motivasi dan dampaknya pada Kinerja pemeriksa Forensik Puslabfor Bareskrim Polri, maka dapat disimpulkan sebagai berikut adalah :

1. Kompetensi berpengaruh positif dan signifikan terhadap Kinerja pemeriksa Forensik Puslabfor Bareskrim Polri, terbukti dengan nilai Koefisien regresi $(\beta)=0,440$ dan nilai $t$ hitung $(4,917)>t$ tabel (1,993), dengan signifikansi 0,000.

2. Disiplin kerja berpengaruh positif dan signifikan terhadap Kinerja pemeriksa Forensik Puslabfor Bareskrim Polri, terbukti dengan nilai Koefisien regresi $(\beta)=0,191$ dan nilai t hitung $(2,177)>t$ tabel $(1,993)$, dengan signifikansi 0,033.

3. Kompetensi berpengaruh positif dan signifikan terhadap Motivasi pemeriksa Forensik Puslabfor Bareskrim Polri, terbukti dengan nilai Koefisien regresi $(\beta)=0,386$ dan nilai thitung $(3,026)>t$ tabel (1,992), dengan signifikansi 0,003.

4. Disiplin Kerja berpengaruh positif dan signifikan terhadap Motivasi pemeriksa Forensik Puslabfor Bareskrim Polri, terbukti dengan nilai Koefisien regresi $(\beta)=0,299$ dan nilai $t$ hitung $(2,343)>t$ tabel 1,992, dengan signifikansi 0,022.
5. Motivasi berpengaruh positif dan signifikan terhadap Kinerja pemeriksa Forensik Puslabfor Bareskrim Polri, terbukti dengan nilai Koefisien regresi $(\beta)=0,355$ dan nilai $\mathrm{t}$ hitung $(4,645)>\mathrm{t}$ tabel $(1,993)$, dengan signifikansi 0,000 .

6. Pengaruh Kompetensi secara langsung lebih besar dari pengaruh tidak langsung terhadap Kinerja pemeriksa Forensik dengan mediasi Motivasi, dimana nilai Koefisien regresi $(\beta)$ untuk pengaruh langsung Kompetensi terhadap Kinerja sebesar 0,440 dan nilai Koefisien regresi $(\beta)$ untuk pengaruh tidak langsung sebesar 0,137. Dalam hubungan Kompetensi dan Kinerja, variabel Motivasi mempunyai pengaruh sebagai Intervening/mediasi terbukti nilai Z hitung $(2,502)>\mathrm{Z}$ tabel $(1,96)$, pada tingkat signifikasi 0,05.

7. Pengaruh Disiplin Kerja secara langsung lebih besar dari pengaruh tidak langsung terhadap Kinerja pemeriksa Forensik dengan mediasi Motivasi, dimana nilai Koefisien regresi $(\beta)$ untuk pengaruh langsung Disiplin Kerja terhadap Kinerja sebesar 0,191 dan nilai Koefisien regresi $(\beta)$ untuk pengaruh tidak langsung sebesar 0,106. Dalam hubungan Disiplin Kerja dan Kinerja, variabel Motivasi tidak mempunyai pengaruh sebagai Intervening/mediasi terbukti nilai Z hitung $(1,789)<\mathrm{Z}$ tabel $(1,96)$, pada tingkat signifikasi 0,05.

8. Kompetensi dan Disiplin Kerja secara simultan berpengaruh terhadap Motivasi pemeriksa Forensik Puslabfor Bareskrim Polri, terbukti dengan nilai $\mathrm{F}$ hitung $(25,463)>F$ tabel $(3,112)$, dengan signifikansi 0,000.

9. Kompetensi, Disiplin kerja dan Motivasi secara simultan berpengaruh terhadap Kinerja pemeriksa Forensik Puslabfor Bareskrim Polri, terbukti dengan nilai $\mathrm{F}$ hitung $(71,088)>\mathrm{F}$ tabel $(2,73)$, dengan signifikansi 0,000 .

\section{SARAN}

Adapun keterbatasan penelitian dan saran yang dapat penulis sampaikan pada bagian akhir penulisan tesis ini adalah sebagai berikut :

1. Penelitian ini hanya melihat pengaruh Kompetensi dan Disiplin Kerja terhadap Motivasi dan Dampaknya pada pemeriksa Forensik Puslabfor Bareskrim Polri, disarankan kepada peneliti berikutnya untuk menambahkan variabel lain yang dapat mempengaruhi Kinerja personil seperti variabel Kepuasan kerja, Iklim organisasi, Kompensasi, Budaya Organisasi dll, agar dapat memahami lebih lanjut mengenai faktor faktor yang dapat mempengaruhi Kinerja. 


\section{Pengaruh Kompetensi Dan Disiplin Kerja Terhadap Motivasi Dan Dampaknya Pada Kinerja Pemeriksa \\ Forensik Puslabfor Bareskrim Polri \\ (Yuswardi)}

2. Keterbatasan penelitian ini adalah pada sampel yang terbatas pada objek Pemeriksa Forensik di Puslabfor Bareskrim Polri. Hal ini mungkin berbeda apabila diperluas kepada pemeriksa Forensik di enam Laboratorium Forensik Cabang seluruh Indonesia yaitu Medan, Palembang, Semarang, Surabaya, Denpasar, dan Makasar. Oleh karena itu perlu dikembangkan penelitian terhadap Pemeriksa Forensik diseluruh Laboratorium Forensik Cabang di Indonesia.

3. Dalam penelitian ini yang menjadi fokus Kinerja adalah penyelesaian berkas perkara yang dilakukan oleh pemeriksa Forensik, sedangkan parameter Kinerja dalam institusi Puslabfor Bareskrim Polri bukan hanya penyelesaian perkara, akan tetapi ada hal-hal lainnya seperti serapan anggaran, kepuasan pelanggan dll. Peneliti selanjutnya dapat mengembangkan penelitian terhadap parameter lainnya dari Kinerja di Puslabfor Bareskrim Polri.

4. Penelitian ini merupakan pendekatan kuantitatif dengan menggunakan kuesioner sebagai teknik pengumpulan data, dimana responden melakukan pengisian kuisioner sebagai data yang akan dianalisis sehingga hasil yang dipaparkan tidak dilengkapi dengan analisis kualitatif. Untuk mendapatkan hasil yang lebih baik diharapkan penelitian lanjutan menggunakan pendekatan kualitatif dan kuantitatif seperti menggunakan teknik wawancara sehingga maksud responden dapat ditangkap dengan sempurna.

\section{DAFTAR PUSTAKA}

A.A. Anwar Prabu Mangkunegara. 2012. Manajemen Sumber Daya Manusia. PT. Remaja Rosdakarya. Bandung

Amir, M. Taufik. 2017. Perilaku Organisasi. PT. Fajar Interpratama Mandiri; Jakarta

Bangun, Wilson. 2012. Manajemen Sumber Daya Manusia. Erlangga; Jakarta

Badriyah, Milla. 2017. Manajemen Sumber Daya Manusia. CV. Pustaka Setia : Bandung

Dahniel, R ycko Amelza dan Dharma, Surya. 2016. Perilaku Organisasi Kepolisian. Pustaka Pelajar. Yogyakarta.

Edison, Emron. Yohny Anwar dan Imas Komariyah. 2017. Manajemen Sumber Daya Manusia : Strategi dan Perubahab dalam Rangka Meningkatkan Kinerja Pegawai dan Organisasi. CV. Alfabeta. Bandung

Ghozali, Imam. 2016. Aplikasi Analisis Multivariate dengan Program SPSS. Edisi Kedelapan. Badan Penerbit Universitas Diponegoro. Semarang
Hasibuan, Melayu. 2016. Manajemen Sumber Daya Manusia. PT. Bumi Aksara ; Jakarta

Irum, et. al. 2014. Impact of Employee Motivation on Employee Performance. European Journal of Business and Management ISSN 2222-1905 (paper) ISSN 2222-2839 (online) Vol. 6 No. 23. 2014.

Guntur Aryo Tejo dan Machasin. 2015. Pengaruh Kompetensi dan Budaya Organisasi terhadap Motivasi Kerja serta dampaknya terhadap Kinerja personel Bid. Humas Polda Riau. Jurnal Tepak Manajemen Bisnis Vol. VII No. 3 September 2015.

Kasmir, 2016. Manajemen sumber Daya Manusia (Teori dan Praktek). PT. Rajagrafindo Persada Depok. Latunreng, Wahyudin. 2013. Manajemen Sumber Daya Manusia : Edisi 3, IPPSDMWIN. Jakarta.

Moeheriono. 2014. Pengukuran Kinerja Berbasis Kompetensi. Edisi Revisi. Rajawali Pers. Jakarta.

Neneng Sofiyanti dan Achmad Nawawi. 2017. Pengaruh Disiplin dan Motivasi Kerja terhadap Kinerja pegawai Satuan Polisi Pamong Praja (Satpol PP) Kabupaten Karawang. Jurnal Buana Ilmu ISSN 2541-6996 Vol. 1 No. 2 Mei 2017.

Notoatmodjo, Soekidjo. 2015. Pengembangan Sumber Daya Manusia. Rineka Cipta. Jakarta.

Peraturan Pemerintah Republik Indonesia Nomor 101 Tahun 2000 tentang Kompetensi pegawai Negeri Sipil

Peraturan Kepala Kepolisian Negara Republik Indonesia Nomor 16 Tahun 2011 tentang Penilaian Kinerja bagi Pegawai Negeri pada Kepolisian Negara Republik Indonesia dengan Sistem Manajemen Kinerja.

Priansa, Donni Junni. 2014. Perencanaan \& Pengembangan SDM. CV. Alfabeta. Bandung

Rivai, Veithzal dan Ella Sagala. 2013. Manajemen Sumber Daya Manusia untuk Perusahaan. Rajawali Pers. Jakarta.

Sedarmayanti. 2017. Sumber Daya Manusia : Reformasi Birokrasi dan Manajemen Pegawai Negeri Sipil. PT. Refika Aditama. Bandung.

Sutrisno, Edy. 2017. Manajemen Sumber Daya Manusia. Kencana; Jakarta

Sinambela, Poltak Lijan. 2017. Manajemen Sumber Daya Manusia. PT. Bumi Aksara; Jakarta

Siagian, Sondang P. 2014. Manajemen Sumber Daya Manusia. PT. Bumi Aksara; Jakarta 
Sugiyono. 2017. Metode Penelitian Kuantitatif dan Kualitatif dan R\&D. CV. Alfabeta. Bandung. Sugiyono dan Agus Susanto. 2015. Cara mudah belajar SPSS \& Lisrer : Teori dan Aplikasi untuk Analisis Data Penelitian. CV. Alfabeta. Bandung. 122

Suparno dan Sudarwati. 2014. Pengaruh Motivasi, Disiplin Kerja dan Kompetensi terhadap Kinerja pegawai Dinas Pendidikan Kabupaten Sragen. Jurnal Paragdigma ISSN : 1693-0827 Volume 12 No. 01 Februari-Juli tahun 2014

Suyitno. 2017. Effect of Competence, Satifaction and Disipline on Performance of Employees in the
Office of Women Empowerment and Familiy Planning of West Papua. Asian Social Sciences ISSN 1911-2017 E-ISSN 1911-2025 Vol. 13, No.5, 2017 Publihed by Canadian Center of Science and Education

Undang-Undang Republik Indonesia Nomor 2 tahun 2002 Tentang Kepolisian Negara Republik Indonesia.

Undang-Undang Republik Indonesia Nomor 13 Tahun 2003 Tentang Ketenagakerjaan.

Widodo. 2017. Metode Penelitian : Populer \& Praktis. Rajawali Pers. Jakarta 